Biografistyka Pedagogiczna

Rok 5 (2020)

ISSN 2543-6112; e-ISSN 2543-7399

DOI: $10.36578 /$ BP.2020.05.15

Oleh Rudenko*

\title{
Leopold Lewicki - nauczyciel bez katedry
}

\section{Leopold Lewicki: A Teacher without a Chair}

\begin{abstract}
The study points to the exclusive role of Leopold Lewicki in the education of the young generation. Through the biography of the outstanding artist of the Krakow Group (the first one) and the memories of the students, the artistic situation, worldview and social changes are analysed. We take into account his period of studies in Krakow before the Second World War and his creative activities after the war in Lviv during the communist regime. Leopold Lewicki did not oppose the government and artists' unions, but he kept a certain distance from Soviet institutions. He gathered people who were spiritually close to him, not using his institutional or social position. He promoted new ideas among young artists, conducted intellectual talks, talked about his own education, analysed works of Western art, gave professional advice and corrected graphic works. In the artistic environment dominated by party ideology and the only art style accepted by the government - socialist realism - Leopold Lewicki helped young graphic artists understand contemporary art, its development and directions. Although not a lecturer, he influenced the creativity of others. The biography of Leopold Lewicki can be an example for today's youth because, in difficult ideological conditions, he not only created unconventional works of art, but also taught outside the university walls.
\end{abstract}

Keywords: Leopold Lewicki, graphics, painting, work of art, students, creativity, Soviet government, totalitarianism.

* Oleh Rudenko (ORCID: 00oo-0oo2-2266-8402) - doc. dr, pracuje w Ukraińskiej Akademii Druku we Lwowie, kontakt: rudenko@wp.pl. 
W ybitny przedstawiciel grupy krakowskiej Leopold Lewicki (urodzony w 1906 r. w Burdiakowce na Podolu, zmarł w 1973 r. we Lwowie) był nieprzeciętną osobowością, człowiekiem, który miał duży wpływ na życie artystyczne we Lwowie po drugiej wojnie światowej. Był niezwykłym nauczycielem, miał ogromny dar nauczania, który rozwijał i wykorzystywał, nie ulegając wpływom ideologii radzieckiej, pod presją której w tych latach znajdowało się społeczeństwo ukraińskie. Chciałbym zaproponować spojrzenie na biografię wybitnego artysty w nieco niekonwencjonalnym ujęciu, biorąc pod uwagę wspomnienia uczniów. Jego spuścizna intelektualno-duchowa i warsztatowa stała się wzorem dla kilku pokoleń grafików lwowskich. Okres jego twórczej działalności we Lwowie przypada na lata 1946-1973 - czasy rządów komunistycznych (rys. 1). Utrzymując pewien dystans wobec instytucji kształtujących młode pokolenie, nie przeciwstawiał się rządowi radzieckiemu ani związkom zawodowym artystów, ale zbierał wokół siebie utalentowaną młodzież, z którą prowadził rozmowy intelektualne, opowiadał o studiach w Krakowie, analizował dzieła sztuki zachodniej. W tym „zatęchłym” środowisku twórczym, zdominowanym przez partyjną ideologię i „socjalistyczny realizm”, obcowanie młodych grafików z Leopoldem Lewickim było jedynym sposobem poznania i zrozumienia sztuki współczesnej i kierunków jej rozwoju. Nie będąc wykładowcą, miał wpływ na twórczość innych i zostawił po sobie wielu uczniów.

\section{Działanie w grupie krakowskiej}

Poglądy artystyczne Leopolda Lewickiego i jego młodzieńcze „bunty” uformowały się w okresie społecznych przemian w latach 1920-1930, kiedy wyjechał na studia do Krakowa. Lewicki był człowiekiem wesołym, lubił opowiadać wice (po lwowsku anegdoty). Przez swoje dobre serce i choleryczny charakter często angażował się w różne sprawy, zwłaszcza polityczne, których do końca nie rozumiał. Świadczy o tym wystąpienie grupki studentów, w którym wziął udział, protestujących przeciwko „starym” sposobom nauczania i prowadzenia zajęć w krakowskiej Akademii Sztuk Pięknych. Inspiracją do udziału w tym buncie przeciwko profesorom było dla Lewickiego niejednoznaczne zachowanie profesora Ksawerego Dunikowskiego i jego krytyka studenckiej pracy młodego artysty. Profesor przyszedł na zajęcia z rzeźbiarstwa, które prowadził jego asystent, miał zrobić korektę prac studentów, a zamiast doradzić młodemu człowiekowi, 
Rys. 1. Jewhen Beznisko, Portret Leopolda Lewickiego, szkic na papierze, kolorowy ołówek, late sześćdziesiąte, Muzeum-pracownia Teodozii Bryż we Lwowie.

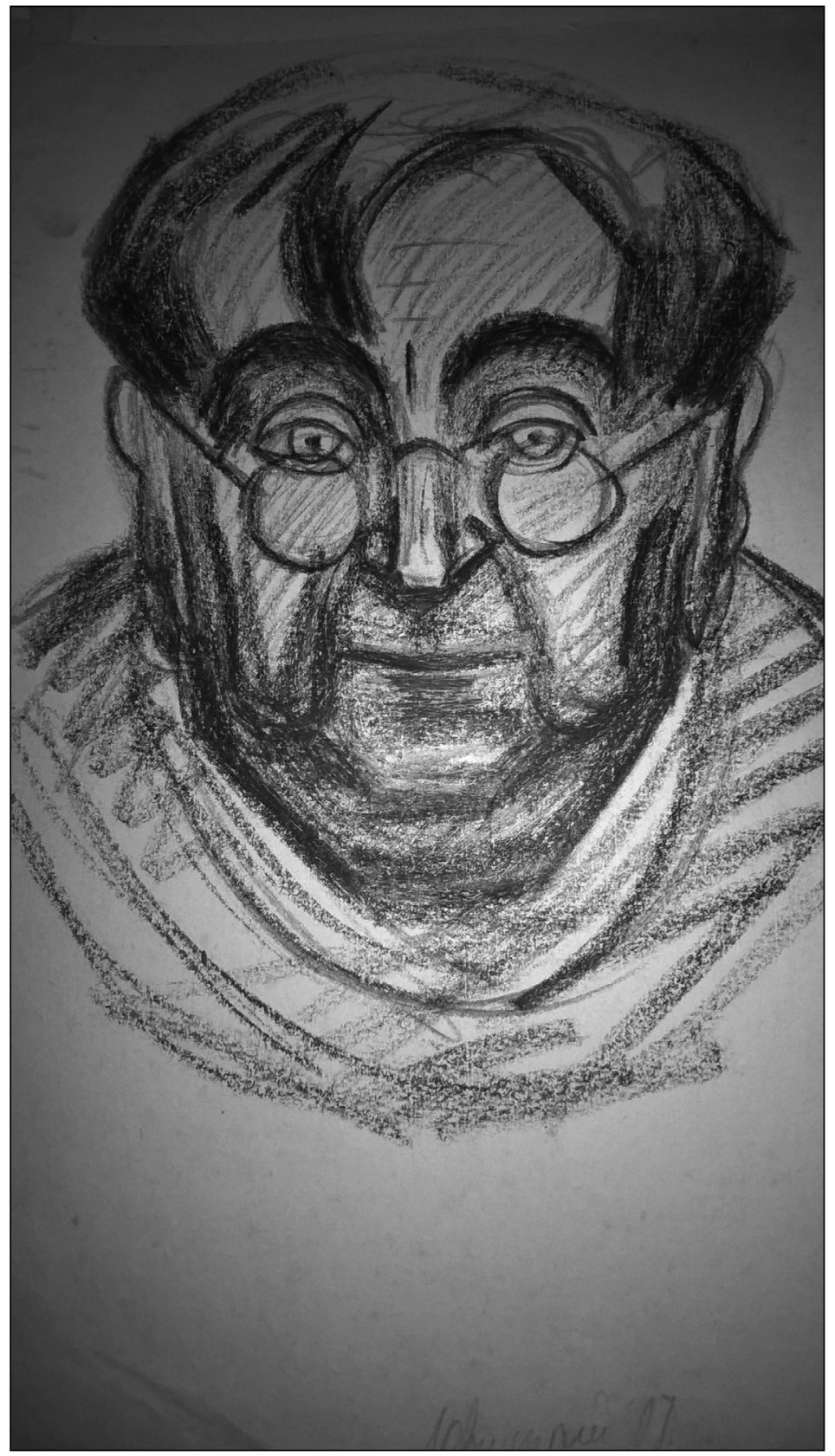


patrząc na jego niewykończoną rzeźbę, powiedział: „Proszę pana, pan byłby dobrym zegarmistrzem!"’. Po tej porażce Lewicki skupił się na grafice.

W 1931 r. w gmachu Akademii miało miejsce wystąpienie studentów-katolików, którzy żądali usunięcia z sal wykładowych Żydów. Lewicki z Henrykiem Wicińskim i Aleksandrem Radziewicz-Winnickim stanęli w ich obro$n^{2}{ }^{2}$. Przeciw akademickiej prawicy uformowano wielonarodowe środowisko lewicowe, powołano stowarzyszenie „Żywi”, grupę tę wspierał Komunistyczny Związek Młodzieży Polski. Wśród członków wspólnoty znajdowali się przyjaciele Lewickiego: Jonasz Stern i Sasza Blonder, Henryk Wiciński i Stanisław Osostowicz. Młody grafik poszukiwał nowych dróg w sztuce, a fascynacja komunizmem i anarchizmem nie była przeszkodą w tworzeniu dzieł abstrakcyjnych.

Z wystawy kończącej rok akademicki w 1932 r. władze uczelni usunęły prace mające charakter antyrządowy. Wśród nich były dzieła Lewickiego. Jak opowiadał grafik, trzeba było coś robić, aby „wszystko powalić”3. Bunt młodych trwał przez trzy dni. Strajkowano, agitowano, porozbijano gipsy wzorów klasycznych, rozwieszono slogany komunistyczne. Ale w końcu trzeba było zakończyć protest i wracać z uczelni do domu. Na ulicy Lewicki został zatrzymany i aresztowany, był przetrzymywany najdłużej ze wszystkich. W rzeczywistości bunt w Akademii został sprowokowany i sfinansowany przez Komunistyczną Partię Polski, która wykorzystała niezgadzających się z programem nauczania artystów.

Po opuszczeniu po trzech tygodniach aresztu Lewicki dowiedział się, że wraz z Osostowiczem i Franciszkiem Jaźwieckim zostali wyrzuceni z Krakowskiej Akademii Sztuk Pięknych. W tym roku młodzieńcy zorganizowali w Związku Zawodowym Polskich Artystów Plastyków wystawę prac artystów odrzuconych. Wtedy wraz z innymi usuniętymi artystami utworzyli tzw. grupę krakowską (pierwszą) ${ }^{4}$.

1 D. Krvavič, Lûdina nenasitnoï žittêvoï energïi, w: Leopol'd Levic'kij: spogadi prohudožnika, red. L. Pavlišin, L'viv 2006, s. 32.

2 M. Besaga, Leopol'd Levic'kij.Vstupna stattâ, w: Leopol'd Levic'kij, red. M. Voloŝak, L'viv 2006, s. 12.

3 D. Krvavič, Lûdina nenasitnoï žittêvoï energïi, s. 33.

4 J. Chrzanowska-Pieńkos, A. Pieńkos, Grupa Krakowska, w: Leksykon sztuki polskiej XX wieku. Sztuki plastyczne, Poznań 1996, s. 77-78. 
Rys. 2. Leopold Lewicki, Kompozycja, papier, akwaforta, 1930-te, ilustracja z książki: Леопольд Левицький (album), red. М. Волощак, Lwów 2006, s. 42.

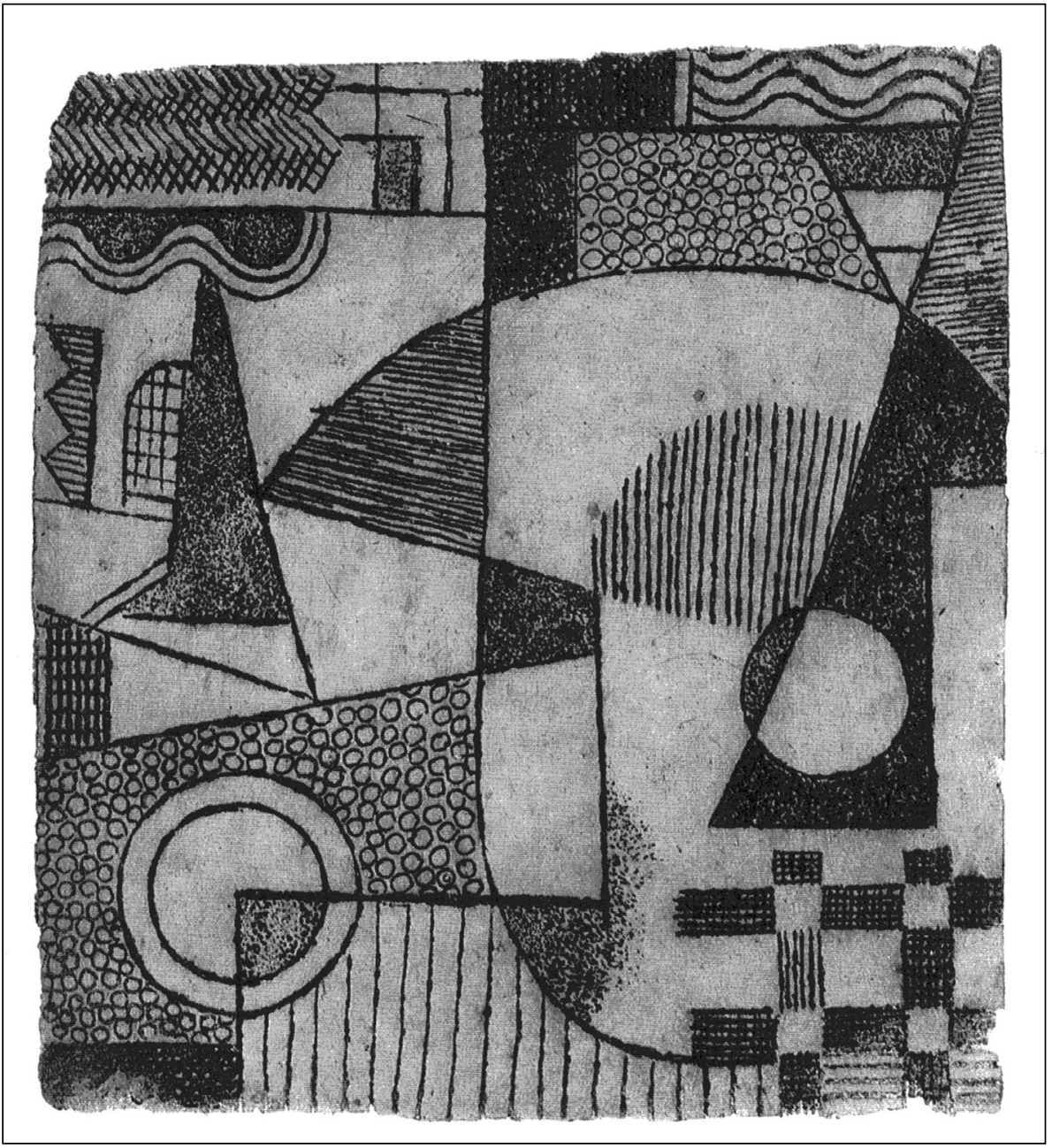

Lewicki otrzymał dyplom krakowskiej Akademii Sztuk Pięknych dopiero w 1961 r. Grafik był raczej nonkonformistą niżeli komunistą, ulegał wpływom, uprawiał też społeczną ironię i satyrę, o czym świadczą jego akwaforty, pokazujące bezczelność i amoralność władzy wobec prostych ludzi („W więzieniu” 1932, „Pogrzeb robotnika” 1932). W tym czasie Lewicki zaczął eksperymentować z płaszczyzną obrazu, tworząc abstrakcyjne kompozycje (rys. 2).

W okresie międzywojennym w polskiej sztuce wiele się działo. Nowych dróg poszukiwali formiści, których wspierał wybitny historyk sztuki Jan Bołoz- 
-Antoniewicz ${ }^{5}$. Nad rozwojem polskiego ekspresjonizmu pracował Leon Chwistek, będący ideologiem tego nurtu, publikował on wiele artykułów, w których ogłaszał zasady nowego kierunku ${ }^{6}$. Chwistek współpracował także z młodymi grafikami: Lewickim (grupa krakowska), Henrykiem Strengiem i Otto Hahnem (grupa Artes). O tych młodych twórcach napisał: „[...] w twórczości ich odnalazłem te same elementy i że zawdzięczam im bardzo wiele"7. Przyznał się także, że temat jednego akwarelowego szkicu, wystawionego w Krakowie w Związku Plastyków, „zawdzięcza akwaforcie Lewickiego”. Widzimy, jak krzyżowały się drogi wybitnych malarzy, zmierzających do stworzenia nowego stylu, zrywającego „z tradycyjnym pojęciem rzeczy, kładąc raczej nacisk na kształty, które obecność rzeczy nadaje atmosferze"8. Chwistek podkreślał, że w żadnym wypadku forma nie może być sama w sobie „czystą”, musi zawierać treść. Zaznaczał, że „nie chciałbym, żeby treść rzeczywista zniknęła z obrazu”.

Moim zdaniem, właśnie niezaangażowana, bezstronna, granicząca z satyrą artystyczna wizja Lewickiego, szkicowość w ukazaniu tematu, deformacja przedmiotów, pokaźna „niedbałość” kreski i plamy, były protestem przeciwko estetyzującym akademickim rysunkom i najbardziej przyciągały otwarty i nieustannie poszukujący nowych doznań i podniet w sztuce umysł Chwistka. Pracując jako profesor na Uniwersytecie, wspierał on młodych artystów grupy krakowskiej, wśród których byli Polacy, Żydzi i Ukraińscy.

W 1933 r. otwarto pierwszą wystawę zrzeszenia we Lwowie ${ }^{10}$. Prezentowane tam dzieła Lewickiego były przepełnione współczuciem dla życia pospolitych ludzi. Widzimy, jak grafik wyszydzał nierówności społeczne i nieco groteskowo ukazywał wydarzenia na akwafortach: „Pogrzeb trzeciej klasy”, „Fabryka”, „Demonstracja”, „Mykwa” (żydowska łaźnia)” (rys. 3). Nigdy później Lewicki nie

5 O. Rudenko, Ân Boloz Antonevič: na storožì pol's'kogo formìzmu, „Vissnik Harkìv'koï deržavnoï akademiï dizajnu ì mistectv", 2012, nr 8, s. 112-115.

6 T. Kostyrko, Leon Chwistek jako filozof sztuki i uczestnik życia artystycznego, w: L. Chwistek, Wybór pism estetycznych, red. T. Kostyrko, Kraków 2004, S. IX-XV.

7 L. Chwistek, Moja walka o nowa formę w sztuce, w: tegoż, Wybór pism estetycznych, S. 247.

8 Tegoż, Formizm, w: tegoż, Wybór pism estetycznych, s. 99-100.

9 Tegoż, Moja walka o nowa formę w sztuce, s. 242.

10 Krakivs'ka grupa. 1932-1937, w: Mistectvo L'vova peršoipolovini HH stolittâ. Katalog vistavki, red. O. Rìpko, L'viv 1996, s. 63. 
Rys. 3. Leopold Lewicki, Mikwe (łaźnia żydowska), papier, akwaforta, sucha igła, lata trzydzieste, ilustracja z książki: Леопольд Левицький (album), red. М. Волощак, Lwów 2006, s. 84.

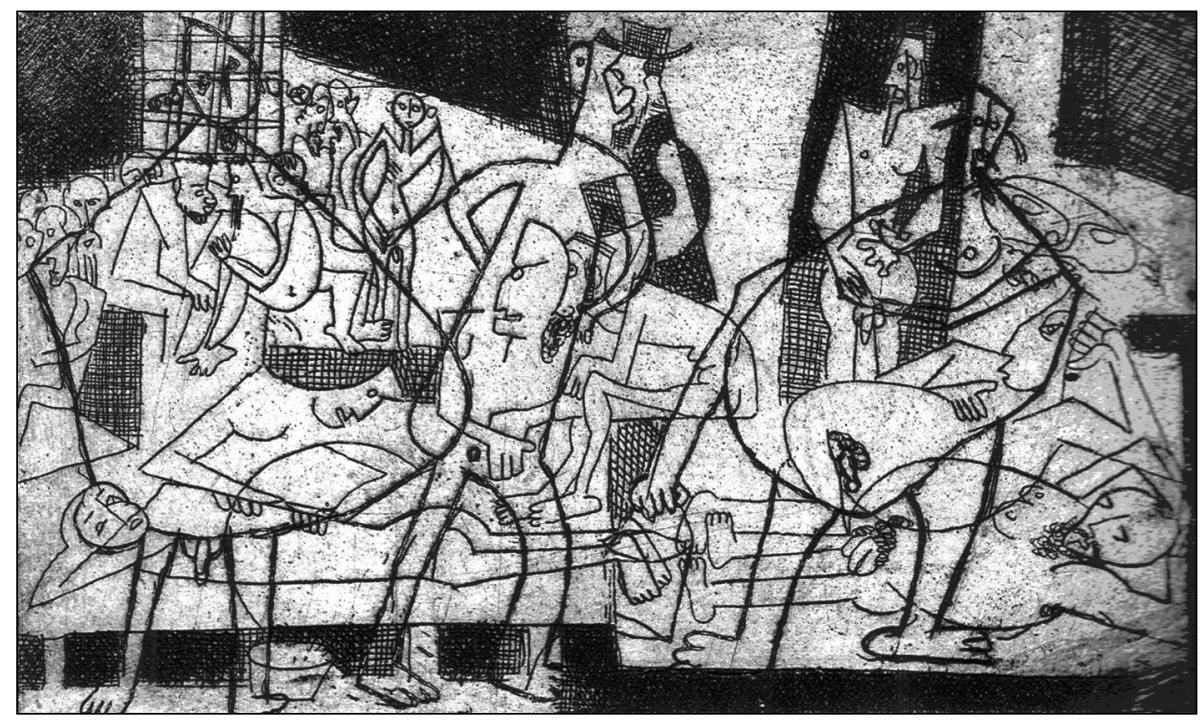

reagował już tak gwałtownie na zmiany i nierówności społeczne tak jak wtedy, zwłaszcza że po wojnie, w czasie rządów radzieckich, mógł podejmować tylko odpowiednie tematy. Młodzieńcze fascynacje komunizmem szybko minęły, ale nie zważając na totalitarne rządy, Lewicki pozostał do końca osobą otwartą, dostępną, człowiekiem, który „nigdy nikomu nie odmawiał rady i chętnie dzielił się wiedzą"11.

\section{Okres po drugiej wojnie światowej}

Opowiadając o życiu Lewickiego, chciałbym jednak skoncentrować się na okresie powojennym, gdy mieszkał on (do końca życia) we Lwowie, który terytorialnie wchodził w skład Ukrainy, należącej do Związku Sowieckiego.

W „zatęchłym” środowisku artystów tworzących w nurcie realizmu socjalistycznego i uznawanej przez rząd jedynej słusznej i prawdziwej linii wytyczanej przez partię socjalistyczną, Lewicki był raczej fenomenem. Z jednej strony dostosował się do życia w Związku Sowieckim, był członkiem lwowskiego

11 [1] İ. Derkač, Deŝo pro žittâ ì tvorčist' L. İ. Levic'kogo, w: Leopol'd Levic'kij: spogadi, s. 18. 
oddziału Związku Radzieckich Artystów Plastyków Ukrainy, a nawet przez jakiś krótki okres, w 1948 r., jego przewodniczącym. Z drugiej strony był człowiekiem, który zachował „ducha” nowej sztuki okresu przedwojennego i niespostrzeżenie, dyskretnie rozwijał własne upodobania, pokazując swoje formalistyczne osiągnięcia wąskiemu gronu artystów. Ci wyjątkowi młodzi malarze i graficy tworzyli środowisko jego przyjaciół i naśladowców. Jak zaznacza jeden z badaczy twórczości Lewickiego, wokół niego „zaczęło formować się kółko uczniów”, którzy chcieli „dołączyć się do prądów europejskich"12. Wśród nich byli m.in. wybitni w przyszłości graficy: Iwan Ostafijczuk, Jewhen Beznisko, Jurij Czarysznikow.

W pośmiertnym wywiadzie żona Lewickiego przyznała, że w wyniku kontaktów z grafikiem uczniowie Lewickiego gruntownie „zmieniali światopogląd" i zapatrywanie na sztukę ${ }^{13}$. On zawsze był chętny do twórczego obcowania z młodymi, doradzał im. Jego profesjonalizm i pedagogiczna wyrozumiałość oraz troska były najlepszym przykładem dla młodych malarzy. Lewicki nigdy nie krytykował i nie narzucał swoich poglądów, tylko proponował kierunek, w którym trzeba podążać, żeby „znaleźć swoją ratowniczą wyspę”14.

Był jednym z nielicznych, którzy w tej powojennej artystycznej, antydemokratycznej „pustyni” radzieckiej pobudzali myśl twórczą. Spośród narzucanych przez Centralny Komitet Partii tematów, poświęconych szczęśliwemu życiu robotników, powiązanych z sowieckimi wojskowymi - wyzwolicielami spod okupacji faszystowskiej, z młodzieżowymi organizacjami, socjalistyczną agitacją, udawało się wybrać te, które dadzą przestrzeń do tego, aby dążyć w stronę formalnych poszukiwań. Nawet gdy podejmował „niezbędne” dla władzy tematy, ujawniał ruch formy poprzez rytmiczną, harmonijną linię i plamy (np. litografia „Ślub” z lat siedemdziesiątych XX W., linoryt „W nowej czytelni”, 1972).

Jednocześnie Lewicki był bardzo wyobcowany w tym totalitarnym społeczeństwie. Taki jest los wielkich ludzi - być niezrozumianym przez innych. Żona

12 V. Semenûk, Formuvannâ ta rozvitok tvorčogo metodu Leopol'da Levic'kogo u kontekstì suspil'no-političnih peretvoren'v Ukraini 1930-1960-h rokiv, „Narodoznavčì zošiti", 2016, nr 5 (131), s. 1209.

13 Tamże, s. 1209.

14 A. Organovič, Nikoli ne slid zaoŝadžuvati na dopomozì bližn'omu, w: Leopol'd Levic'kij: spogadi, s. 110. 
Lewickiego po śmierci męża powiedziała: „On zmarł z powodu samotności”15. Bardzo bolało Lewickiego to, że musiał dla pieniędzy, na zamówienie, tworzyć dzieła w nurcie ideologii radzieckiej: portrety pisarzy ukraińskich i rosyjskich, wybitnych działaczy partyjnych. Akceptował ten stan, ale coraz bardziej otwierał się na kontakty z innymi, zwłaszcza młodszymi od siebie, „przyciągał ich jak magnes"16. Jak wspomina Czarysznikow, Lewicki był tym, do którego można było wprost przyjść i poprosić o radę, ponieważ był otwarty, a jednocześnie twórczy, nikt nie dorównywał mu, podziwiano jego profesjonalizm w grafice.

Wśród uczniów Lewickiego chciałbym wyróżnić wybitnych artystów, z którymi bezpośrednio się kontaktowałem i którzy prezentują dwa różne kierunki w sztuce - Ostafijczuka i Czarysznikowa. Twórczość pierwszego inspirowana była motywami ludowymi o korzeniach huculskich. Drugi był bardziej kosmopolityczny, swoją wizję grafiki koncentrował na konceptualnych poszukiwaniach formy. Te dwa kierunki krzyżowały się w późniejszych pracach artystów lwowskich końca XX w. Uczniowie Lewickiego osiągnęli sukces twórczy jeszcze za czasów rządów radzieckich. Iwan Ostafijczuk w 1989 r. zdobył złoty medal na IX biennale grafiki w Brnie, za monotyp do ukraińskich piosenek ludowych (rys. 4-5), natomiast Jurij Czarysznikow był m.in. odznaczony „Złotym jabłkiem” w Bratysławie w 1983 r. za ilustrowanie „Aventurile baronuluj Mjunchauzen” („Przygody barona Munchausena”), a w 2008 r. otrzymał Grand Prix za szatę graficzną (z wkorzystaniem litograficznych odcisków) książki Mikołaja Gogola Opowiadania petersburskie na XXI moskiewskim międzynarodowym konkursie książki (rys. 6-7). Po latach wspominał on, że to właśnie Lewicki jako pierwszy odkrył i rozpoznał w nim talent i wskazując palcem na pierś młodzieńca, powiedział: „Z tego chłopca będzie wielki pożytek”"17.

W latach sześćdziesiątych aż do końca osiemdziesiątych we Lwowie prężnie działał ośrodek litograficzny, który znajdował się na parterze Uniwersytetu Lwowskiego im. Iwana Franki. Pracowały tam dwie prasy drukarskie do litografii i jedna do wklęsłego druku. W tym dużym pomieszczeniu pod szklanym dachem zbierała się sekcja graficzna Lwowskiego Związku Artystów, żeby

15 Wywiad z Jurijem Czarysznikowym, przeprowadził O. Rudenko, Lwów, 23 czerwca 2016, Archiwum autora, s. 1.

16 G. Ostrovs'kij, Spogadi, w: Leopol'd Levic'kij: spogadi, s. 132.

17 Wywiad z Jurijem Czarysznikowym, s. 1. 
Rys. 4. Iwan Ostafijczuk, motyw piosenki ludowej Tam za gajem gaj, monotypia, 1978, Archiwum Iwana Ostafijczuka.

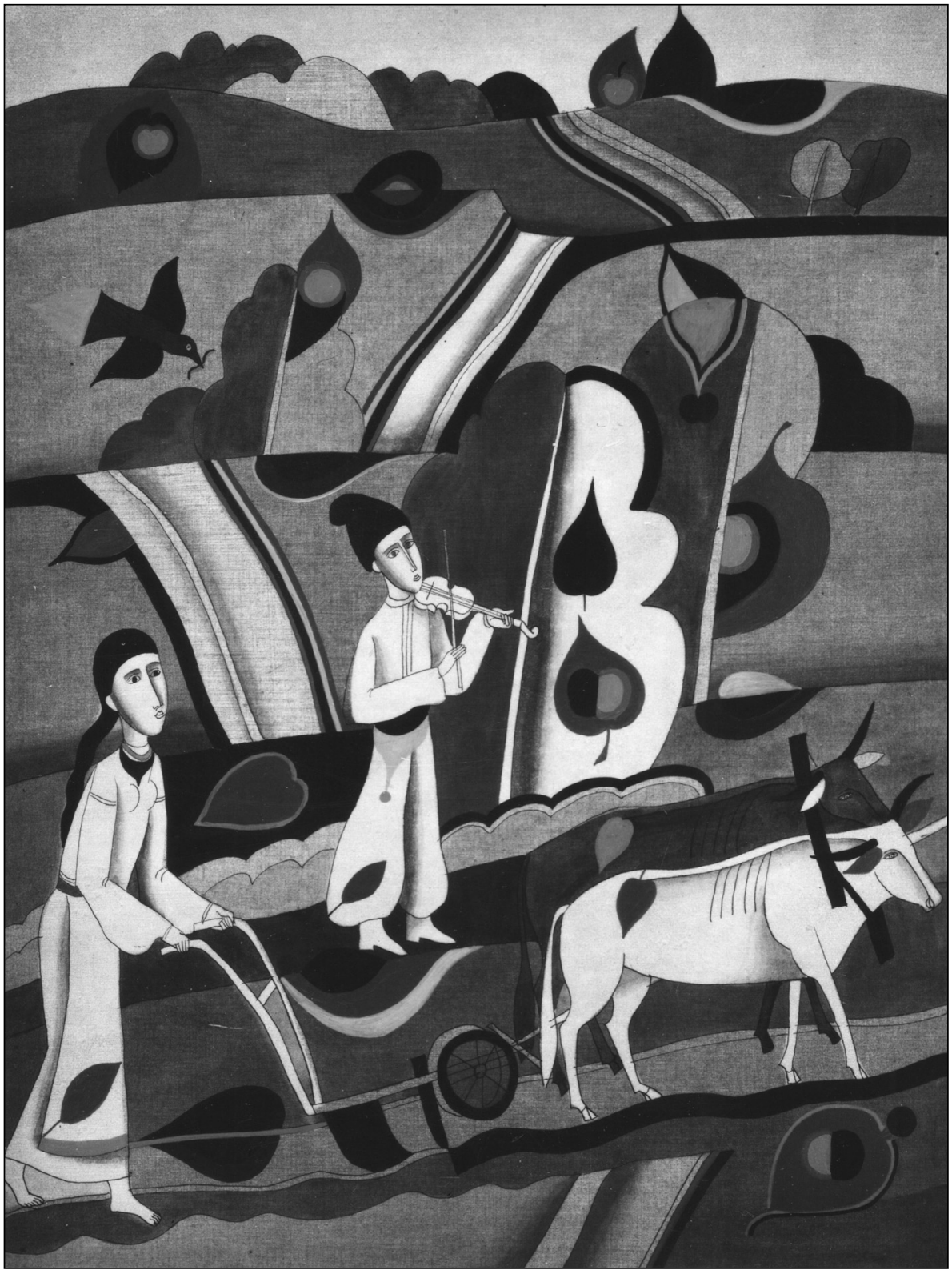


Rys. 5. Iwan Ostafijczuk, motyw piosenki ludowej Pokochała młodego skrzypka, monotypia, 1978, Archiwum Iwana Ostafijczuka.

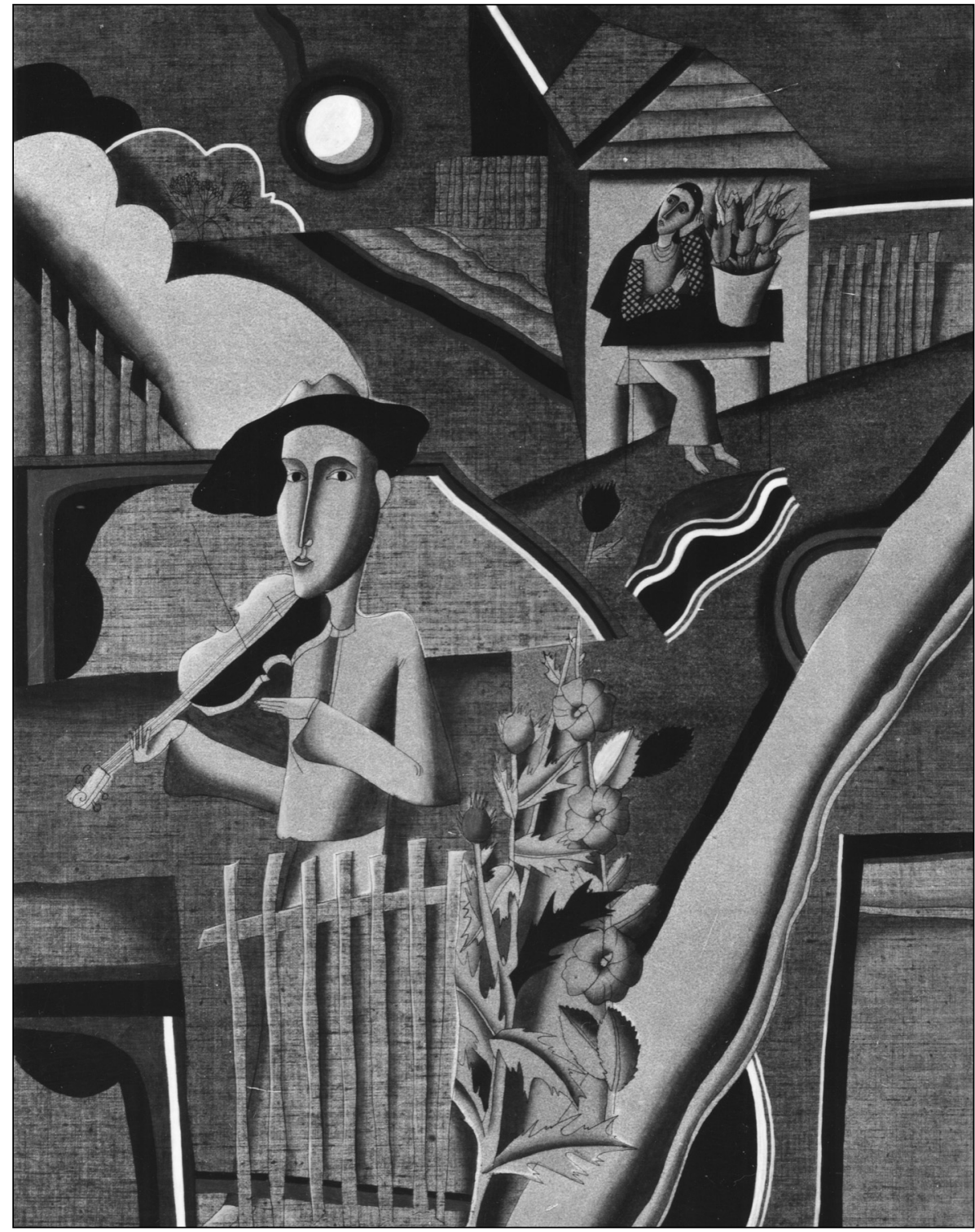


Rys. 6. Jurij Czarysznikow, „Burza” z cyklu „Przygody barona Munchausena”, litografia, 1982, kolekcja prywatna.

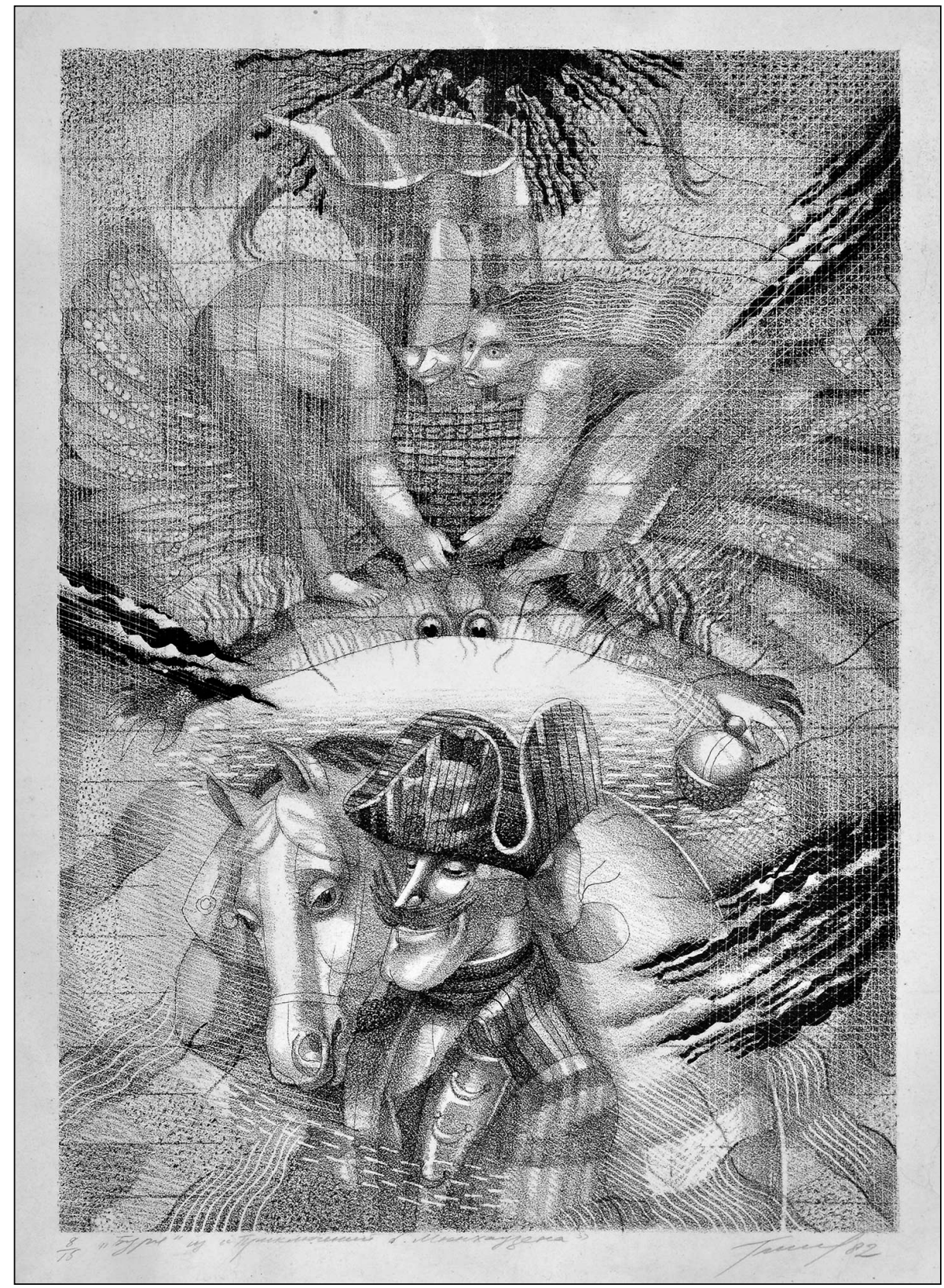


Rys. 7. Jurij Czarysznikow, okładka książki Mikołaja Gogola „Opowiadania petersburskie”, litografia, lata osiemdziesiąte, ilustracja z okładki książki: Н. Гоголь, Петербургские повести, Kijów 2008.

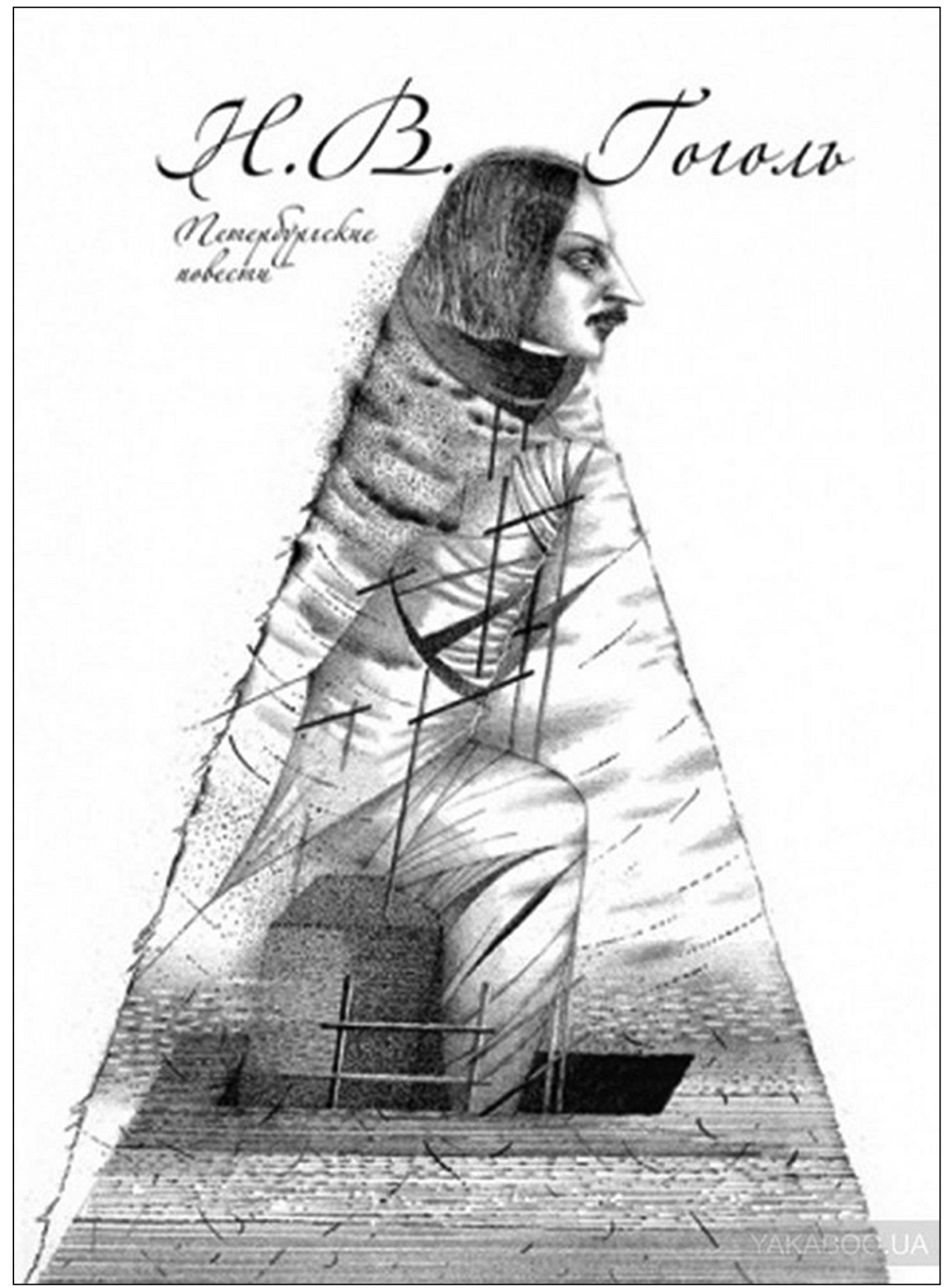


drukować zamówienia. Ale oprócz związkowców przychodziła młodzież, która chciała pogłębić wiedzę teoretyczną i techniczną, a także, będąc studentami, dorabiała sobie na życie. Takie duże towarzystwo zbierało się w samym centrum Lwowa i, obok realizacji zamówień, tworzyło wiele dzieł dla siebie i przyjaciół. Obok Lewickiego pracowali tam znani graficy, m.in.: Henrietta Lewicka, Czarysznikow, Wolodymyr Pinigin, Kateryna Sujewałowa, Walerij Demianyszyn, Bohdan Pikulitski, Ołeksa Szatkiwski, Ivan Katruszenko, Zenowij Kecało. W pracowni litograficznej toczyły się dyskusje i odbywała wymiana zdań i poglądów na tematy społeczne i światopoglądowe, padały pytania dotyczące sztuki i kompozycji. Prawdopodobnie dlatego Wołodymyr Ostrowski napisał, nieco hiperbolizując, że Lewicki „nigdy nie był uczelnianym wykładowcą, ale z całą pewnością każdy lwowski grafik naprawdę może uważać się za jego ucznia”18. Jak podkreśla Czarysznikow, to był chyba jedyny grafik ze „starszej” generacji, który posiadał znaczną wiedze i był otwarty na rozmowy i chętnie uczył i udzielał rad, chociaż nigdy nie stworzył własnej szkoły ${ }^{19}$. Przecież kontakty z grafikami, wymiana zdań podczas pracy na uniwersytecie były czymś zwyczajnym. Ale trzeba też zauważyć, że w pracowniach uniwersytetu nie wolno było rozmawiać o wszystkim, ponieważ działał tam Komitet Bezpieczeństwa Państwowego, który nadzorował produkcje i pilnował, aby na prasach drukarskich nie drukować niedozwolonych rzeczy: dokumentów państwowych, ulotek czy plakatów agitacyjnych. Zawsze po wyczerpaniu nakładu jeden egzemplarz zostawał w pracowni na wypadek kontroli zewnętrznej. Mimo iż pilnowano tego, co działo się w pracowniach, zawsze znajdowała się jakaś przerwa wykorzystywana na druk wolnej twórczości - wojskowi nie zawsze, a często nigdy, nie mogli zrozumieć, o co chodzi w tej lub innej pracy twórczej, tym bardziej abstrakcyjnej. Rygor dotyczył przede wszystkim produkcji na zamówienie, a także napisów antyrządowych, symboliki i portretów działaczy zakazanych lub treści, które pospolity obywatel radziecki mógł zrozumieć nie tak, jak trzeba.

Jak wspomina Ostafijczuk, na bardziej szczere rozmowy na tematy światopoglądowe chodziło się do pracowni, która znajdowała się na sąsiedniej ulicy.

18 G. Ostrovskij, Leopol'd Levickij, Moskva 1978, c. 5.

19 Wywiad z Jurijem Czarysznikowym, s. 1. 
Po lampce wina Lewicki opowiadał o biennale grafiki w Polsce, nowych trendach w sztuce, młodzieńczym przedwojennym życiu w Krakowie, gdzie po wojnie mieszkał jego przyjaciel z grupy krakowskiej Jonasz Stern. Lewicki utrzymywał z nim kontakty i od niego bezpośrednio otrzymywał informacje o życiu artystycznym za granicą. Częstym gościem w tej pracowni był inny przyjaciel Lewickiego, wykładowca uniwersytecki, filozof i teoretyk Igor Sandurski. Wtedy rozmowy i dyskusje przenosiły się w stronę rozważań nad koncepcjami Georga Wilhelma Friedricha Hegla i Ludwiga Feuerbacha.

Zazwyczaj Ostafijczuk demonstrował swoje pracę i prosił o radę. Potem Lewicki pokazywał swoje i analizował. Lewicki uczył myśleć, często mówił, że w każdym graficznym dziele sztuki, do którego przystępuje artysta, „musi być zawarta jakaś »mucha«", to znaczy zawoalowana tajemnica, jakiś ukryty sens ${ }^{20}$. Namawiał do tworzenia, brał czysty arkusz papieru i zachęcał do „walki” z nim, wskutek której powstawał obraz. Była to swobodna wymiana poglądów, komunikacja „na równych” zasadach, i w taki sposób odbywało się samokształcenie, dojrzewanie osobistości młodego grafika. Wtedy, w trudnych czasach autokratycznego reżimu, kiedy młody Ostafijczuk szukał własnej drogi i obcował z mistrzem, zaczął krystalizować się ludowy etnograficzny kierunek jego prac, w których chciał on wyrazić miłość do ziemi rodzimej, uwydatnić oryginalność narodu ukraińskiego. Możemy nawet prześledzić wzajemny wpływ jednego grafika na drugiego. Przecież w linorytach Lewickiego („Siedziba” 1968 (rys. 8), „Początek dnia” 1968, „W górach” 1969) i Ostafijczuka („Dowbusz jedzie” 1965, „Muzycy” 1968, „W górach” 1968) , powstałych w latach sześćdziesiątych, można odnaleźć podobieństwo w aranżacji płaszczyzn, które charakteryzują się zastosowaniem graficznej tekstury, w zależności od tego, w jakim kierunku ułożono linie tworzące plamę albo oddzielone czarną lub białą linią. U Lewickiego kreska była bardziej delikatna i wyrafinowana, podczas gdy u Ostafijczuka odczuwa się młodzieńczy zapał i entuzjazm, a plamy organizujące płaszczyznę obrazu są bardziej intensywne. W późniejszym okresie u Ostafijczuka widoczne były bardziej „suche”, dekoracyjne linie, ułożone w kształty małych trójkątów, które są typowe dla rzeźb huculskich (ilustracje z 1969 r. do opowiadań Wasyla Stefanyka Kamienny krzyż (rys. 9), „Palij” itp.)

20 Wywiad z Iwanem Ostafijczukiem, przeprowadził O. Rudenko, Lwów, 20 grudnia 2016, Archiwum autora, s. 1. 
Rys. 8. Leopold Lewicki, Siedziba, papier, linoryt, 1968, ilustracja z książki:

Леопольд Левицький (album), red. М. Волощак, Lwów 2006, s. 191.

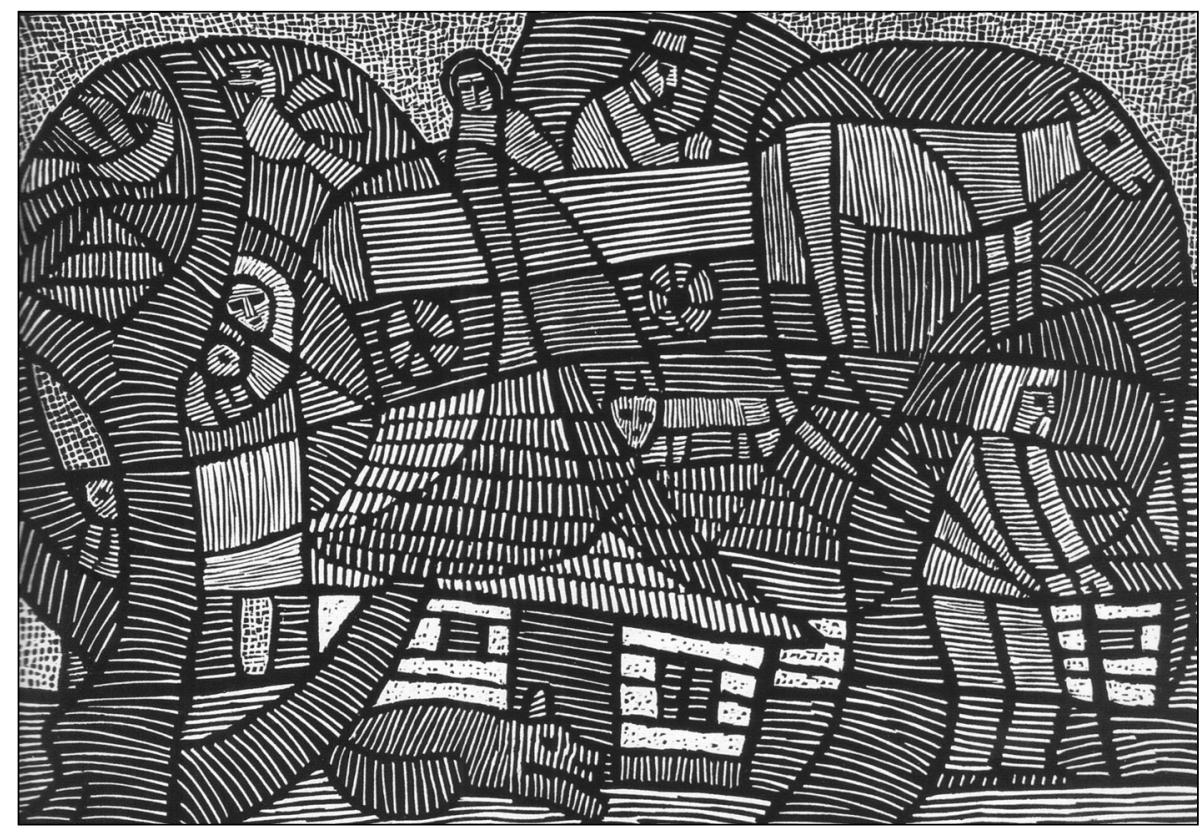

Jak wskazuje Ostafijczuk, najbardziej tajemnicze rzeczy o idei narodowej omawiali, idąc ulicą, żeby nikt nie mógł podsłuchać. Lewicki bardzo niepokoił się, kiedy w latach sześćdziesiątych przeprowadzono areszty ukraińskich dysydentów, szczególnie martwił się, gdy do więzienia została wtrącona artystka Stefania Szabatura.

Lewicki, nie był nacjonalistą, ale podobnie jak jego żona, bardzo lubił swoją ziemię ojczystą, zwłaszcza region, w którego wywodzili się - zachodnie Podole. Żona artysty - Gienia (Eugenia), z pochodzenia Żydówka, znała dużo ludowych ukraińskich piosenek, które często śpiewała. Lewicki mógł wyjechać do Polski, gdzie mieszkał jego przyjaciel Stern, ale nie chciał opuszczać stron rodzinnych.

Ostafijczuk przypomina sobie, że w korytarzu mieszkania Lewickiego przy wejściu, jako symbol tej miłości, wisiała bardzo „ciepła” grafika, na której ukazana była dziewczyna w stroju ludowym, ilustrująca piosenkę Gala niesie wodę. Łatwa do odczytania alegoria, odkrywała poglądy Lewickiego, że „sztuka musi 
Rys. 9. Iwan Ostafijczuk, Kamienny krzyż, papier, linoryt, 1969, ilustracja z książki: М. Бесага, Іван Остафійчук (альбом-монографія), Kјów 2013, s. 69.

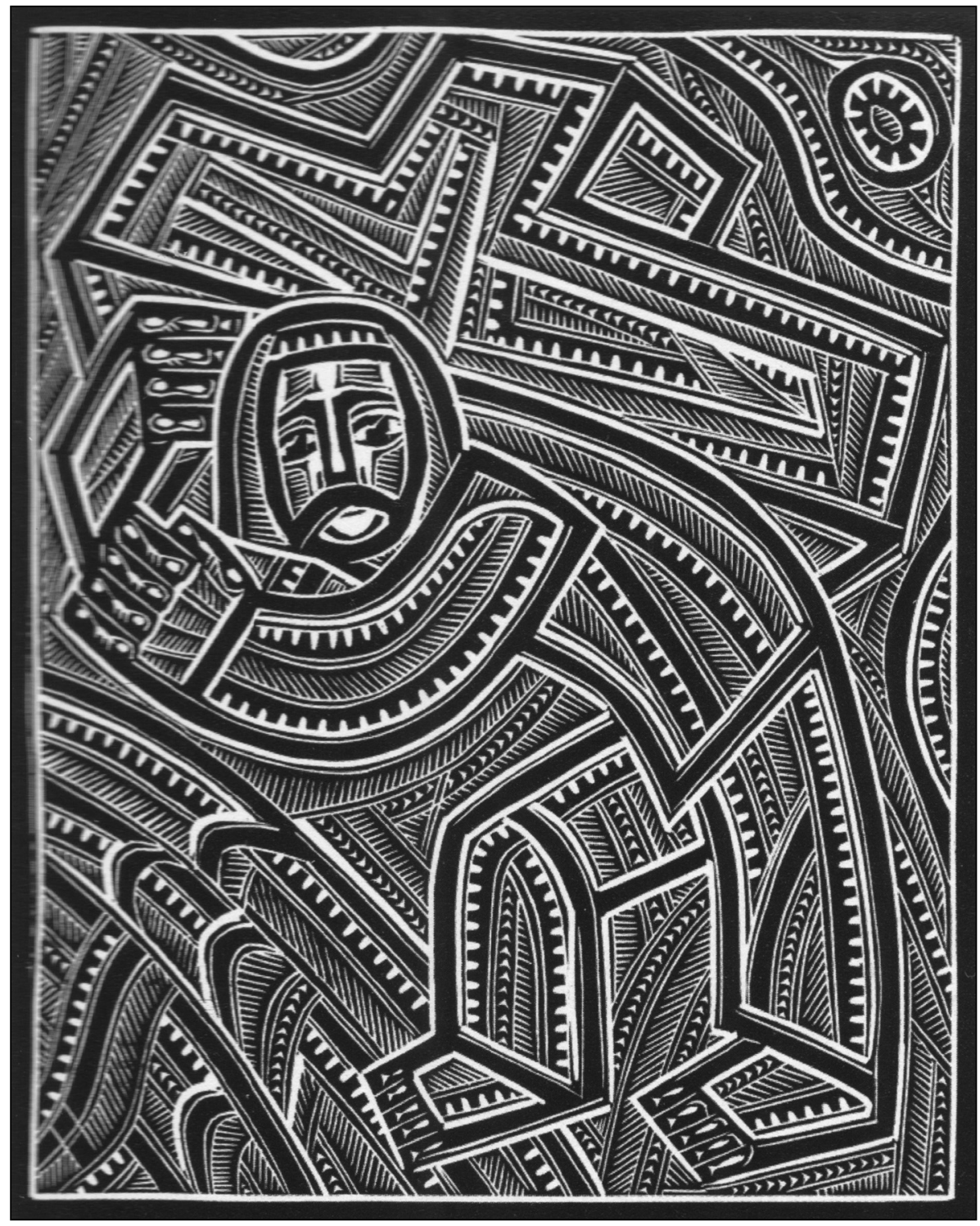


Rys. 10. Leopold Lewicki, Muzyki Jazzu, papier, linoryt, lata sześćdziesiąte, ilustracja z książki: Леопольд Левицький (album), red. М. Волощак, Lwów 2006, s. 165.

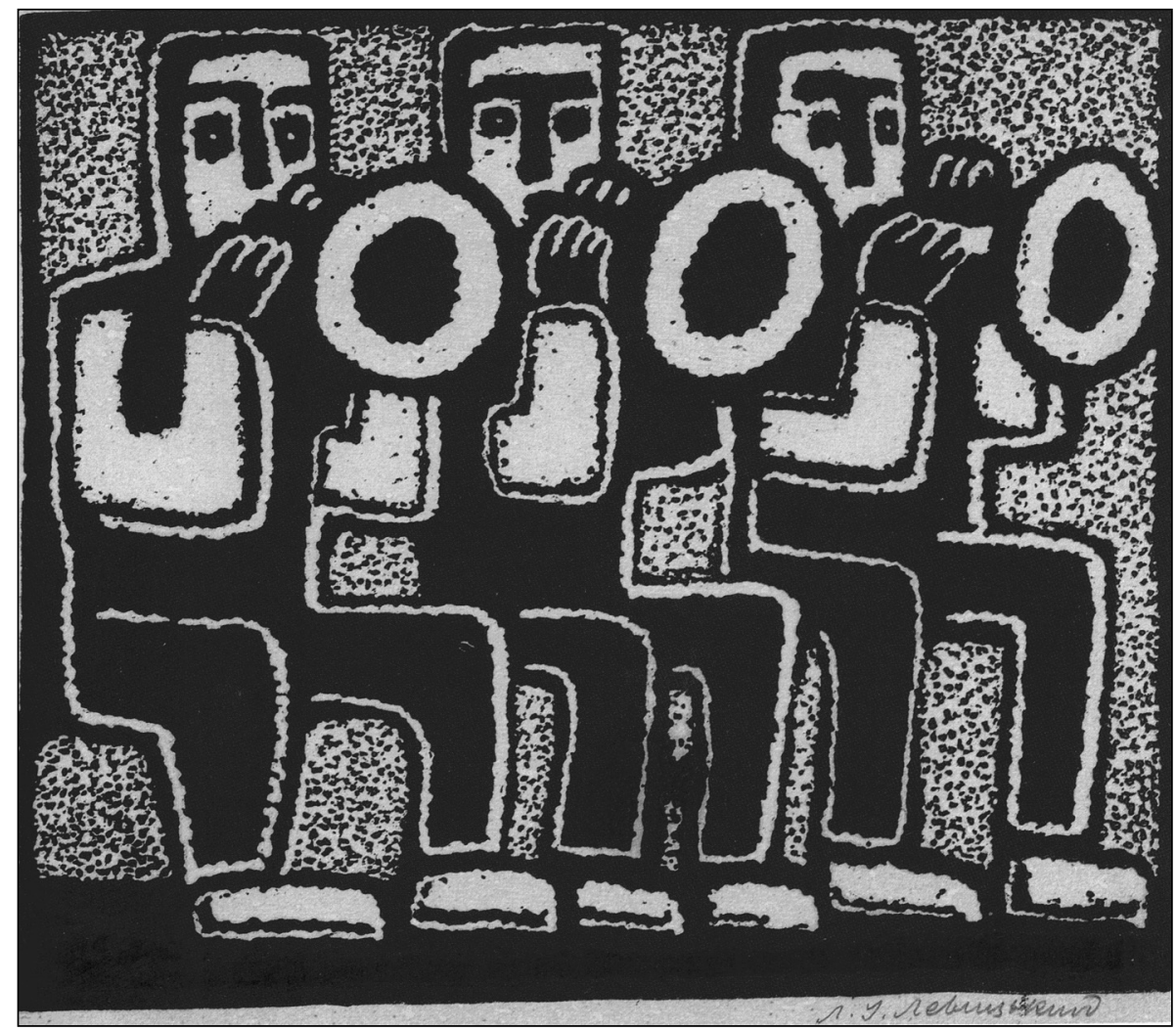

być prosta” ${ }^{21}$. Nie tolerował dużych graficznych „płócien”. Uważał, że grafika powinna być oglądana w odległości wyciągniętej ręki, żeby można było skupić się zarówno na całości, jak i tak na detalach. Natomiast Czarysznikow wspominał, jak Lewicki mówił o tym, że „malarz powinien odczuwać czas”22. Dlatego, będąc na studiach w Krakowie, mistrz tworzył jedną grafikę, a później inną. On zachwycał się dwiema innymi obrazami, które wisiały w domu Lewickiego, były to „Wróżka z kotem” i „Muzyka jazzu” (rys. 10). Widzimy, jak każdy z początkujących artystów brał od Lewickiego to, co mu było najbliższe. Grafik niczego nie narzucał, rozmawiano o pracach, sztuce... Czarysznikow wspominał: „pomiędzy

21 Tamże, s. 1.

22 Tamże, s. 1. 
Rys. 11. Leopold Lewicki, Miasto, papier, linoryt, koniec lat sześćdziesiątych, ilustracja z książki: Леопольд Левицький (album), red. М. Волощак, Lwów 2006, s. 219

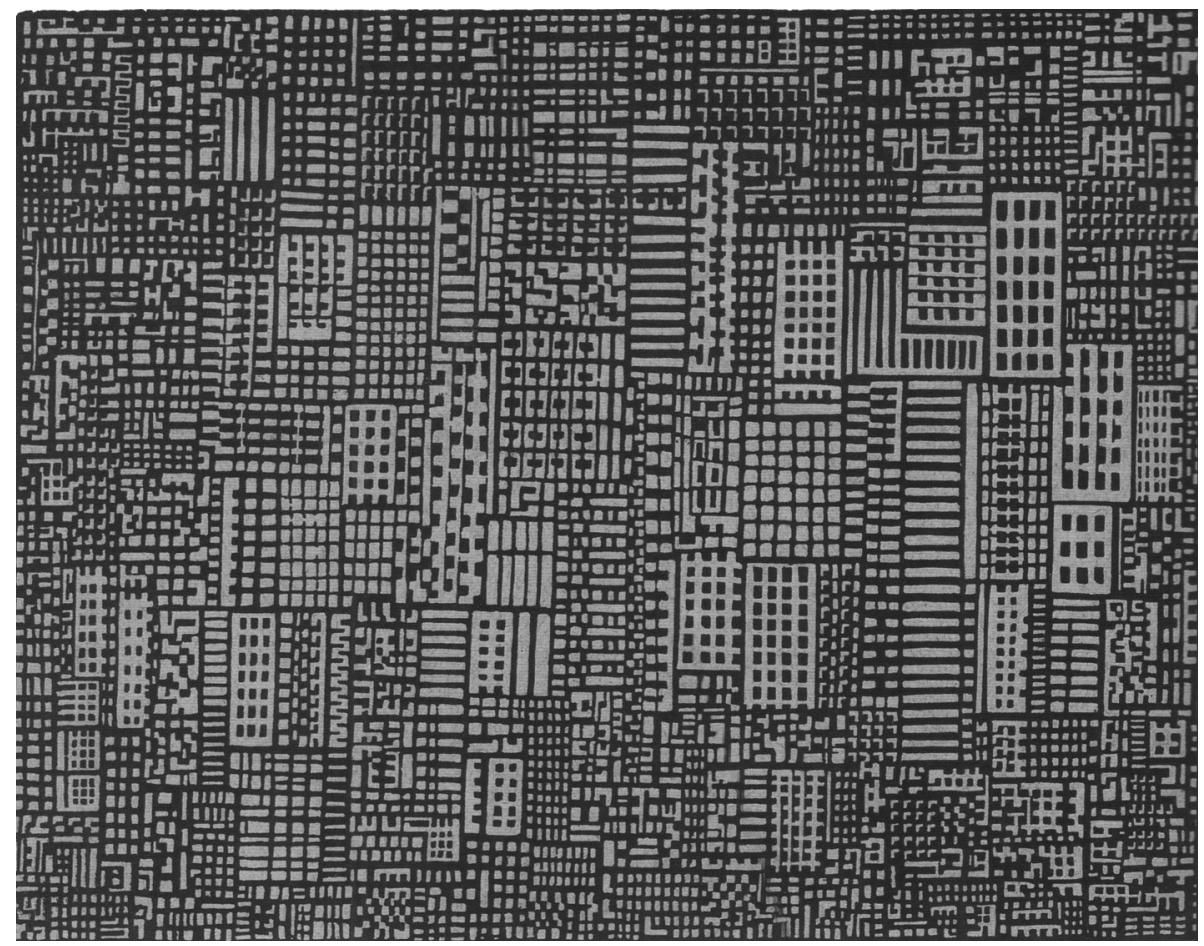

nami panowała cicha miłość ku sztuce"23. To samo można powiedzieć o stosunkach Lewickiego z innymi uczniami. Chociaż na wiele problemów Czarysznikow nie znalazł odpowiedzi u Lewickiego, ale inspirowany jego sposobem myślenia doszedł do tego po jakimś czasie. Uważał, że Lewicki najbardziej ujawnił siebie w pracach „płaszczyznowego” charakteru, natomiast sam Czarysznikow poszukiwał przejawów materii duchowej, która „krzyżuje się” w obrębie płaszczyzny obrazu i uobecnia przez różne graficzne formy. Świat otaczający nas jest podobny do struktury wielowarstwowych komórek pszczół, przepełnionych uczuciami, przeżyciami, dźwiękiem, słowem itd., które grafik powinien wyrazić przez obraz wizualny.

Kiedy grafik Zinowij Kułykowec przyniósł do Lewickiego swoją pracę, mistrz spojrzał, zastanowił się i powiedział do niego: „Kolego, to nie pasuje tak malować.

23 Tamże. 
Musi być synteza - podporządkowanie, współzależność różnych plam graficznych między sobą" ${ }^{24}$. Chodziło o wzajemne powiązanie kresek i plamy graficznej, które powinny tworzyć pewną hierarchiczną subordynację, stosując różnorodne tekstury. „Tak, więc, to jest podobne do człowieka - gdy rodzi się, uczy się chodzić, a potem wstaje i chodzi przez całe życie, a pod koniec bierze laseczkę nie prosto tak, a żeby nie przewrócić się ${ }^{25}$. Lewicki namalował kwadrat i podzielił go prostopadłymi liniami na mniejsze kwadraty. W kwadratach natychmiast ukazał "mocne" plamy o różnym uderzeniu kreski od najsubtelniejszej „pajęczyny” do grubych, wygiętych esowatych linijnych przycisków, wyrażając w ten sposób estetykę kreski, znaczenie każdej plamy, która tworzyła całościową sekwencję asocjacyjną.

W taki nieskomplikowany sposób Lewicki wyjaśnił innemu grafikowi jak artysta powinien czynić, żeby stworzyć dzieło abstrakcyjne. Lewicki dużo palił, dlatego zawsze miał przy sobie zapałki. „Spójrzcie, to pudełko ma sześć grani, ale zazwyczaj odbiorca widzi trzy. Jeżeli namalujecie pudełko tak, żeby było widać wszystkie sześć grani - to taki obraz będzie waszym pierwszym utworem abstrakcyjnym!"26. Lewicki przez całe życie poszukiwał nowych rozwiązań. Chociaż musiał tworzyć na zamówienie, zawsze „bronił pozycji skrajnej awangardy”27. Uczył młodych artystów niezaangażowanego myślenia, twierdził, że nawet w deformacji formy może być piękno. W tym wyrażał się jego umysł estety i grafika.

Bardzo naiwny, niewysokiego wzrostu i grubiutki Leopold Lewicki często popadał w sytuacje anegdotyczne. Jego żona mówiła, że „Leopold nie lubi kłamstw, ale on wejdzie w kłamstwo, i nie zauważy, jak cały ubrudzi się"28. Leopold Lewicki swoje abstrakcyjne utwory wykonywał w „warunkach podziemia" i pokazywał tylko zaufanym przyjaciołom ${ }^{29}$. Zazwyczaj byli to młodzi uczniowie. Prace takie przechowywane były wewnątrz kanapy żony Lewickiego - Geni. Ciekawy jest fakt "przypadkowego” nagrodzenia Lewickiego orderem Lenina, właśnie m.in. za te „zakazane” utwory. Pisarze lwowscy pokłó-

24 Wywiad z Zinowijem Kułykowcem, przeprowadził O. Rudenko, Lwów, 1 marca 2018, Archiwum autora, s. 1.

25 Tamże.

26 A. Organovič, Nikoli ne slìd zaoŝadžuvati, s. 111.

27 D. Krvavič, Lûdina nenasitnoižittêvoï energiï, w: Leopol'd Levic'kij: spogadi, s. 31.

28 Wywiad z Jurijem Czarysznikowym, s. 1.

29 M. Batìg, Leopol'd Levic'kij - učitel' ì učen', w: Leopol'd Levic'kij: spogadi, s. 47. 
cili się o tę nagrodę, ale minister kultury Związku Radzieckiego pani Furcewa, przebywając we Lwowie, musiała komuś przekazać przywiezioną z Moskwy odznakę i wtedy zadecydowano zwrócić uwagę na działania artystów. Doradzono jej pójść do pracowni grafika i ona z całym otoczeniem partyjnym przyszła do Lewickiego i prosiła, aby pokazał coś oryginalnego. Wtedy nieoczekiwanie Leopold Lewicki wyciągnął dzieła abstrakcyjne, wśród których była seria „Miasto". Pani minister to niekonwencjonalne podejście bardzo się spodobało i powiedziała: „Это хорошо!”. Niebawem Lewicki otrzymał wyróżnienie ${ }^{30}$.

W takim trybie "wtajemniczonego" obcowania w pracowniach i poza nimi, wykonywania zamówień partyjnych, pogrywania z władzą radziecką, produkowania dzieł poza wystawowymi itd., przeciekało życie artystyczne we Lwowie. Ale na wszystkich, którzy byli bliskimi przyjaciółmi Lewickiego, sprawiła wrażenie nieoczekiwana śmierć artysty. Dla Czarysznikowa „oberwała się nić życia" i wtedy uświadomił on sobie, że wszystko jest marnością i szybko przemija. Naokoło zapanowało twórcze pustkowie, miało się wrażenie, że skończyła się cała epoka - epoka Lewickiego. Jak wpomina Irina Sobolewa, kiedy Lewicki zmarł, to „leżał na stole w ciasno zapiętej marynarce, duży, unieruchomiony, niezwykle skuty. Nas było tylko dwoje: ja i młody, bardzo utalentowany, zakochany w Leopoldzie Iwanowiczu artysta-grafik Jurij Czarysznikow. Obydwoje zapłakaliśmy tak, jak płaczą po stracie bardzo bliskiej osoby... rozpadło się koło, w którym on był niepodważalnym centrum"31.

\section{Podsumowanie}

Biografia Leopolda Lewickiego może być przykładem dla dzisiejszej młodzieży, ponieważ w trudnych warunkach upolitycznionej rzeczywistości on nie tylko tworzył dzieła sztuki, ale nauczał poza ścianami uczelni. Zbierał obok siebie ludzi bliskich duchowo, nie zważał na stanowiska czy tytuły. Jak wspominają współcześni, Leopold Lewicki zawsze „był przepełniony różnorodnymi ideami, przez całe życie miał bardzo młodą duszę i nigdy nie przerwał twórczych poszukiwań"32. Ograniczenia nałożone na społeczeństwo przez totalitarny system

30 Wywiad z Iwanem Ostafijczukiem, s. 2.

31 I. Soboleva, Ušlacelaâ èpoha radosti, w: Leopol'd Levic'kij:spogadi, s. 125.

32 A. Organovič, Nikoli ne slìd zaoŝadžuvati, s. 111. 
państwa sowieckiego zmuszały Lewickiego, aby w swojej pracy twórczej był „podwójnym”. Ta „rozpiętość" twórcza była wymuszona: dla przedstawicieli władzy radzieckiej tworzył dzieła na zamówienie, dla pieniędzy, natomiast dla siebie tworzył „do szuflady”. Pokazywał te prace uczniom, z którymi chętnie dzielił się własnymi spostrzeżeniami. Było to bardzo osobiste, ukryte przed władzami, ale znane innym, gdyż bez tego nie mógł żyć. Czasami jego prace pojawiały się na wystawach, gdyż partyjni działacze nie rozumieli nowoczesnej sztuki i nie wiedzieli, co przedstawia konkretna grafika, a nazwa nie stała w sprzeczności do partyjnej ideologii, np. „Samochody i ludzie”. Według Ostafijczuka, Lewicki nie chciał robić wystawy retrospektywnej dzieł własnych, gdyż nie chciał obok twórczego dorobku ukazać portretów działaczy radzieckich, zamawianych i wykonywanych dla pieniędzy, mówił: „Nie chcę, bo wtedy muszę ukazać portret Tereszkowej i inne postaci radzieckie" ${ }^{\prime 3}$.

Po drugiej wojnie światowej, kiedy granice państwowe nabrały nowych kształtów, a Lwów znalazł się na radzieckiej Ukrainie, prace i styl życia Leopolda Lewickiego zajęły szczególne miejsce. Nie poszedł on do pracy w żadnej instytucji edukacyjnej, odmawiając kontynuowania kariery profesorskiej, ponieważ był świadomy, że radziecka akademia sztuki preferowała „wiarygodnych" nauczycieli. Jednak jego praca artystyczna i propedeutyczna stały się przykładem cichej, nierzucającej się w oczy miłości ku sztuce. On równolegle poruszał się w stronę „wymuszonego" realizmu, preferowanego przez rząd radziecki, i dążył w kierunku sztuki abstrakcyjnej, stylizując płaszczyznę obrazu, ucinając i nakładając jedną na drugą plamę, wykorzystując różnorodną fakturę. Będąc przedstawicielem artystycznej elity europejskiej, nie wyjechał, a pozostał wśród nielicznych grafików we Lwowie, otwarty na komunikację z innymi. Lewicki nie porzucił awangardowych osiągnięć poprzedników, ale umiejętnie przekształcił je w warunkach rzeczywistości socjalistycznej. Jego formalistyczne poszukiwania, dzięki którym ujawnił się oryginalny talent artysty, łączyły wiedzę i umiejętności zdobyte w okresie międzywojennym, gdy kształcił się jako artysta w Paryżu i Krakowie, z osiągnięciami powojennymi.

Młodym artystom trudno było kontaktować się i współpracować z zagranicą, a wyjeżdżać ze Związku Radzieckiego można było tylko „wybranym”, którym władza na to pozwoliła. Taka utrudniona komunikacja ze światem była

33 Wywiad z Iwanem Ostafijczukiem, s. 1. 
zwyczajną sprawą w antydemokratycznym społeczeństwie, w którym istniała jedyna partia, wyznaczająca „korytarz” tematyczny dla artystycznych działań. Dlatego młodzi otoczyli Lewickiego i wsłuchali się w każde jego słowo, słuchali o grupie krakowskiej, studiach przedwojennych, nurtach sztuki współczesnej. W umyślnie „uciętym” światopoglądowo środowisku cały szereg grafików, obcując z nim, przyswajał sobie niekonwencjonalne idee, uzupełniał i rozwijał progresywne pomysły. Pod wpływem fachowego i duchowo dojrzałego źródła, którym był Lewicki, wśród młodych grafików powstało całe morze strukturalnych, wyidealizowanych, metaforycznych osiągnięć: od naśladowania wzorów zakotwiczonych w sztuce ludowej - do konceptualnej awangardowej grafiki. Artyści, poruszeni Lewickim, poszukiwali oryginalnych i nowoczesnych środków wyrazu. Dlatego rozwój lwowskiej grafiki drugiej połowy Xx w. wiele zawdzięcza utalentowanej osobowości Lewickiego. Widzimy, jak dzięki niezaangażowanemu wolnemu nauczaniu Lewicki stał się dla nielicznych uczniów prawdziwym „guru", profesorem bez katedry, który nauczał poza ścianami akademii $\mathrm{w}$ „duchu greckim" przez rozmowę, wymianę zdań i dyskusję.

Streszczenie: W opracowaniu wskazuje się na wyłączną role wychowania młodego pokolenia przez Leopolda Lewickiego. Przez biografię wybitnego artysty Grupy Krakowskiej (pierwszej) i wspomnienia uczniów, analizuje się sytuacja artystyczna, światopoglądowa, zmiany społeczne. Bierzemy do uwagi okres studiów w Krakowie przed Drugą Wojną Światową i działalność twórczą po wojnie we Lwowie w czasy reżimu komunistycznego. Leopold Lewicki nie przeciwstawiał się rządowi, ani związkom zawodowym artystów, ale utrzymywał pewien dystans wobec instytucji radzieckich. Zbierał obok siebie ludzi bliskich duchowo, a nie stanowiskiem instytucjonalnym lub społecznym. Propagował wśród młodych artystów nowe idee, prowadził rozmowy intelektualne, opowiadał o własnym kształceniu, analizował dzieła sztuki zachodniej, doradzał fachowo, robił korektę prac graficznych. W środowisku artystycznym, zdominowanym przez partyjną ideologię i jedyny uznawany przez rząd kierunek sztuki - socjalistyczny realizm, obcowanie z Leopoldem Lewickim było sposobem dla młodych grafików zrozumieć sztukę współczesną, jej rozwój i kierunki. Nie będąc wykładowcą, miał wpływ na twórczość innych. Biografia Leopolda Lewickiego może być przykładem dla młodzieży dzisiejszej, ponieważ w trudnych ideologicznych warunkach on nie tylko tworzył niekonwencjonalne dzieła sztuki, ale nauczał poza ścianami uczelni.

Słowa kluczowe: Leopold Lewicki, grafika, obraz, dzieło sztuki, uczniowie, twórczość, rząd radziecki, totalitaryzm. 


\section{Bibliografia}

Besaga M., Leopol"d Levic'kij.Vstupna stattâ, w: Leopol'd Levic'kij, red. M. Voloŝak, Lwów 2006.

Chrzanowska-Pieńkos J., Pieńkos A., Grupa Krakowska, w: Leksykon sztuki polskiej XX wieku. Sztuki plastyczne, Poznań 1996.

Leon Chwistek. Wybór pism estetycznych, red. T. Kostyrko, Kraków 2004.

Leopol'd Levic'kij:spogadi pro hudožnika, red. L. Pavlišin, Lwów 2006, c. 32.

Mistectvo L'vova peršoïpolovini HH stolittâ. Katalog vistavki, red. O. Rìpko, Lwów 1996.

Ostrovskij G., Leopol'd Levickij, Moskwa 1978.

Rudenko O., Ân Boloz Antonevič: na storožì pol's'kogo formìzmu, „Vìsnik Harkivs'koï deržavnoï akademiï dizajnu ìmistectv", 2012, nr 8.

Semenûk V., Formuvannâta rozvitok tvorčogo metodu Leopol'da Levic'kogo u kontekstìsuspil'no-političnih peretvoren' v Ukraïnì 1930-1960-h rokiv, „Narodoznavčì zošiti”, 2016, nr 5 (131).

Wywiad z Iwanem Ostafijczukiem, przeprowadził O. Rudenko, Lwów, 20 grudnia 2016, Archiwum autora.

Wywiad z Jurijem Czarysznikowym, przeprowadził O. Rudenko, Lwów, 23 czerwca 2016, Archiwum autora.

Wywiad z Zinowijem Kułykowcem, przeprowadził O. Rudenko, Lwów, 1 marca 2018, Archiwum autora. 